\title{
Correction: Acute post stroke depression at a Primary Stroke Center in the Middle East
}

\author{
Stacy Schantz Wilkins, Naveed Akhtar, Abdul Salam, Paula Bourke, Sujatha Joseph, \\ Mark Santos, Ashfaq Shuaib
}

The following information is missing from the Funding section: This article was funded by the Qatar National Library. The funder had no role in study design, data collection and analysis, decision to publish, or preparation of the manuscript.

\section{Reference}

1. Wilkins SS, Akhtar N, Salam A, Bourke P, Joseph S, Santos M, et al. (2018) Acute post stroke depression at a Primary Stroke Center in the Middle East. PLoS ONE 13(12): e0208708. https://doi.org/10. 1371/journal.pone.0208708 PMID: 30571716

\section{G OPEnACCESS}

Citation: Wilkins SS, Akhtar N, Salam A, Bourke P, Joseph S, Santos M, et al. (2019) Correction: Acute post stroke depression at a Primary Stroke Center in the Middle East. PLoS ONE 14(2): e0212919. https://doi.org/10.1371/journal.pone.0212919

Published: February 21, 2019

Copyright: ๑ 2019 Wilkins et al. This is an open access article distributed under the terms of the Creative Commons Attribution License, which permits unrestricted use, distribution, and reproduction in any medium, provided the original author and source are credited. 